\title{
Extracellular enzyme activities potentially involved in the pathogenicity of Mycobacterium tuberculosis
}

\author{
Catherine Raynaud, Gilles Etienne, Pascale Peyron, \\ Marie-Antoinette Lanéelle and Mamadou Daffé
}

Institut de Pharmacologie et de Biologie Structurale du CNRS \& Université Paul Sabatier, 205 route de Narbonne, 31077 Toulouse cedex, France
Author for correspondence: M. Daffé. Tel: +33561 1755 69. Fax: +33561175994. e-mail : daffe@ipbs.fr

To evaluate the potential contribution of extracellular enzymes to the pathogenicity of mycobacteria, the presence of selected enzyme activities was investigated in the culture filtrates of the obligate human pathogen Mycobacterium tuberculosis, M. bovis BCG, the opportunistic pathogens $M$. kansasii and $M$. fortuitum, and the non-pathogenic species $M$. phlei and $M$. smegmatis. For $M$. tuberculosis and $M$. bovis, 22 enzyme activities were detected in the culture filtrates and/or cell surfaces, of which eight were absent from the culture fluids of non-pathogens: alanine dehydrogenase, glutamine synthetase, nicotinamidase, isonicotinamidase, superoxide dismutase, catalase, peroxidase and alcohol dehydrogenase. These activities, which correspond to secreted enzymes, formed a significant part (up to $92 \%$ ) of the total enzyme activities of the bacteria and were absent from the culture fluids and the cell surfaces of the non-pathogenic species $M$. smegmatis and $M$. ph/ei. The extracellular location of superoxide dismutase and glutamine synthetase seemed to be restricted to the obligate pathogens examined. The difference in the enzyme profiles was not attributable to the growth rates of the two groups of bacteria. The presence of the eight enzyme activities in the outermost compartments of obligate pathogens and their absence in those of non-pathogens provides further evidence that these enzymes may be involved in the pathogenicity of mycobacteria. In addition, the eight enzyme activities were demonstrated in the cell extract of $M$. smegmatis. Stepwise erosion of the cell surface of $\boldsymbol{M}$. smegmatis to expose internal capsular constituents showed that the various enzyme activities, with the possible exception of superoxide dismutase, were located more deeply in the cell envelope of this bacterium. This suggests that the molecular architecture of the mycobacterial envelopes may play an important role in the pathogenicity of these organisms.

Keywords: tuberculosis, Mycobacterium, extracellular protein, enzyme, pathogenicity

\section{INTRODUCTION}

There has been a resurgence in diseases resulting from infections with mycobacteria in the last 25 years. More people died from tuberculosis in 1995 - about 3.1 million - than in any other year in history, according to the 1996 report of the World Health Organization (Moran, 1996). Almost 2 billion people-one-third of the world's population - have been infected with Mycobacterium tuberculosis, the causative agent of tuberculosis, of whom $5-10 \%$ will develop the active disease. Tuberculosis is becoming a major health problem in industrialized countries, due to the emergence of drugresistant strains and the coincidence of tuberculosis and HIV infection (Bloom \& Murray, 1992).

In spite of the considerable body of work devoted to deciphering the molecular basis of mycobacterial pathogenicity, little is known about the mechanisms by which the facultative intracellular pathogenic species, notably M. tuberculosis, are capable of resisting destruction and multiplying inside mononuclear phagocytic cells. The peculiar structure and composition of the mycobacterial cell envelope (Daffé \& Draper, 1998) is nevertheless 
thought to account for the organisms' virulence to a large extent (Daffé, 1996). This conclusion is based on several intriguing observations, including the fact that virulent mycobacteria growing intracellularly are surrounded by a capsule. This may be part of a defence mechanism permitting all mycobacterial pathogens to resist being killed by phagocytic cells (Draper \& Rees, 1970). The protective capsule not only controls access from the medium to the inside of the mycobacterial cell but also determines what components come into contact with host cells and tissues (Daffé \& Draper, 1998). The outermost constituents of the bacilli, which include the extracellular material released by actively growing miycobacteria in artificial culture media, are composed primarily of protein and carbohydrate (Lemassu \& Daffé, 1994; Lemassu et al., 1996; Ortalo-Magné et al., 1995).

During the last few years, there has been a significant change in our knowledge about the tactics used by pathogenic micro-organisms to infect their hosts (Cossart et al., 1996). In particular, attention has focused on the proteins secreted by microbial pathogens which are implicated in their virulence (see Sears \& Kaper, 1996). Many of these proteins, for example the bacterial proteinases (Travis et al., 1995), have sufficient enzyme activity to account for their toxicity. In the case of mycobacteria, the presence of enzyme activities in cultures of $M$. tuberculosis has been known for a long time. Some of these activities were determined in agar cultures, generally to identify the species (Tsukamura, 1981). Other activities have been examined directly from culture supernatant (Casal \& Linares, 1984; Kannan et al., 1987). In both cases, however, and due to extensive autolysis which occurs in cultures of mycobacteria, the question of the exact localization of these activities remained. More recently, the nature of the extracellular material released from $M$. tuberculosis during its different growth phases has been reinvestigated by several authors. These studies firmly established that the culture filtrates from the early growth phase, in which the bacterial lysis was minimal, contained secreted proteins (Abou-Zeid et al., 1986; Andersen et al., 1991; Nagai et al., 1991; Ortalo-Magné et al., 1995) which may also be defined by quantitative means (Wiker et al., 1991). Although numerous studies have been devoted to the antigenic properties of these secreted polypeptides (for reviews see Andersen \& Brennan, 1994; Young et al., 1992), little attention has been paid to their enzymic activities. Nevertheless, based on their distribution between pathogenic and non-pathogenic strains and their putative biological role, five proteins, namely superoxide dismutase (Zhang et al., 1991), alanine dehydrogenase (Andersen et al., 1992), glutamate synthetase (Harth et al., 1994), thioredoxin (Wieles et al., 1995) and phospholipase C (Johansen et al., 1996) have been regarded to some extent as virulence determinants. The present study compared the enzyme profiles of the extracellular materials of the obligate pathogens M. tuberculosis and M. bovis, the opportunistic pathogens M. kansasii and M. fortuitum, and the saprophytic $M$. smegmatis and $M$. phlei. To distinguish between those activities due to secreted proteins and those caused by the release of cell-envelopeassociated or cytosolic proteins, the enzyme activities were monitored throughout the different growth phases of $M$. tuberculosis and M. smegmatis and three enzymes with well-known locations in the different compartments of the cell were used as standards.

\section{METHODS}

Strains and growth conditions. Mycobacterium bovis (BCG Pasteur, CIPT 140040001), M. fortuitum (ATCC 6841), M. kansasii (ATCC 12478), M. phlei (ATCC 11758), M. smegmatis (ATCC 607), and M. tuberculosis H37Rv (ATCC 27294), H37Ra (ATCC 25177) and strain Canetti (CIPT 140010059) were inoculated by loop (roughly $10 \mathrm{mg}$ wet bacteria) into $100 \mathrm{ml}$ Sauton's medium (Sauton, 1912) in a $250 \mathrm{ml}$ flask and incubated at $37^{\circ} \mathrm{C}$ as surface pellicles for the periods indicated.

Production of the culture filtrates. The pellicle growth conditions enabled cells to be easily harvested by permitting the medium to be collected while the pellicles remained attached to the flasks. The culture broths were collected, sterilized by filtration through a $0 \cdot 2 \mu \mathrm{m}$ sterile Nalgene filter (Nalge) and concentrated under vacuum to one-tenth of the original volume. Tween 80 was added to an aliquot of the concentrated filtrates $(1 \%, \mathrm{w} / \mathrm{v})$ to determine the possible influence of the detergent on both the qualitative enzyme activity profile and the protein concentration (see below). The remaining culture fluids were precipitated twice with 6 vols cold ethanol to eliminate most of the salts. The precipitates were collected after centrifugation at $14000 \mathrm{~g}$ for $1 \mathrm{~h}$, dissolved in distilled water and dialysed against distilled water. Protein concentration was determined by the Coomassie blue reaction (Bio-Rad protein assay) and the filtrates were adjusted to $50 \mu \mathrm{g}$ protein $\mathrm{ml}^{-1}$ by evaporation under vacuum at room temperature.

Isolation of surface-exposed and internal capsular materials. The surface-exposed materials were recovered from surface pellicle grown cells as described by Ortalo-Magné et al. (1995). Briefly, mycobacterial cells were harvested and gently shaken for $1 \mathrm{~min}$ with $10 \mathrm{~g}$ glass beads ( $4 \mathrm{~mm}$ diameter) per $2 \mathrm{~g}$ (wet wt) cells. The resulting declumped cells were suspended in distilled water $(50 \mathrm{ml}$ per flask $)$ and immediately sterilized by filtration as described above. In a parallel experiment, the original culture medium of actively growing cells was replaced by fresh Sauton's medium containing $1 \%$ $(\mathrm{w} / \mathrm{v})$ Tween 80 , and the cells were shaken at $37^{\circ} \mathrm{C}$ for 1,4 or 24 h (Ortalo-Magné et al., 1996). Cells were then harvested by centrifugation and treated with glass beads as described above. The filtrates derived from the treatment of bacilli with Tween 80 and/or glass beads were concentrated separately under vacuum to one-tenth of the original volume. The presence of Tween did not modify the enzyme profile of the culture filtrates tested but did lead to an overestimation of protein concentration. For this reason the culture filtrates derived from the treatment of bacilli with Tween 80 were precipitated twice with 6 vols cold ethanol to eliminate most of the salts and Tween 80 . The precipitates were collected after centrifugation at $14000 \mathrm{~g}$ for $1 \mathrm{~h}$, dissolved in distilled water and dialysed overnight at $4{ }^{\circ} \mathrm{C}$. The resulting materials were concentrated under vacuum to adjust their protein concentration to $50 \mu \mathrm{g} \mathrm{ml}^{-1}$ and their enzyme profiles analysed. 
Subcellular fractionation of $\boldsymbol{M}$. smegmatis and $\boldsymbol{M}$. tuberculosis. The culture filtrates were carefully collected and the cell pellicles were treated with glass beads (Ortalo-Magné et al., 1995) to disperse clumps and resuspended in cold phosphatebuffered saline (PBS; $0 \cdot 16 \mathrm{M} \mathrm{NaCl}, 0 \cdot 15 \mathrm{M}$ sodium phosphate buffer, $\mathrm{pH}$ 7.2) supplemented with $3 \mathrm{mM} 2$-mercaptoethanol. $M$. smegmatis cells from the mid-exponential growth phase were broken using a French pressure cell (Aminco) at 24000-26000 p.s.i. (165-180 kPa) and the disrupted cells were centrifuged for $15 \mathrm{~min}$ at $3000 \mathrm{~g}$. In the case of M. tuberculosis and the remaining mycobacteria examined, wet cells $(6 \mathrm{~g})$ were mixed with $12 \mathrm{~g}$ precooled $\left(-20^{\circ} \mathrm{C}\right)$ ballotini in a chilled mortar; cells were thoroughly ground in a safety cabinet (MSC III) for $15 \mathrm{~min}$ to yield a pale yellow cream. The mixture was resuspended in $20 \mathrm{ml}$ cold PBS and centrifuged for $30 \mathrm{~min}$ at $3000 \mathrm{~g}$ to eliminate the unbroken cells. The $3000 \mathrm{~g}$ supernatants obtained from all the mycobacterial species examined (the cell extracts), which consisted of cytosol and cell envelopes, were recentrifuged for $20 \mathrm{~min}$ at $20000 \mathrm{~g}$. The pellets resulting from this centrifugation were assumed to consist mainly of cell envelopes; the supernatants, representing mixtures of cytoplasmic components and cell membranes, were filtered through a $0.2 \mu \mathrm{m}$ membrane (Nalge).

Determination of enzyme activities. To prevent any bacterial contamination during the incubation experiments, chloramphenicol and gentamicin (Sigma) at a concentration of $100 \mu \mathrm{g} \mathrm{ml}^{-1}$ were systematically added to the assays. The presence of possible microbial contamination was carefully checked after each long enzyme incubation. All enzyme activities were assayed at least three times at the recommended $\mathrm{pH}$; absorbance was determined in cuvettes $(1 \mathrm{~cm}$ path length) using a Perkin-Elmer UV/Vis spectrometer Lambda 16.

The API ZYM test (bioMérieux) was used to detect the presence of 19 enzyme activities according to the manufacturer's instructions. Samples $(70 \mu \mathrm{l})$ of the fractions were added to each cupule of the strips; after incubation, the colour was allowed to develop for $5 \mathrm{~min}$, following the addition of the manufacturer's reagents, and the enzyme activities were graded according to the intensity of colour with the API ZYM colour reaction chart.

Isocitrate dehydrogenase activity was assayed using the ICD diagnostic kit for quantitative determination (Sigma), with changes in $A_{340}$ corresponding to the reduction of NADP to NADPH. A Sigma unit for isocitrate dehydrogenase activity was defined as the quantity of enzyme that produced $1 \mathrm{nmol}$ $\mathrm{NADPH}$ in $1 \mathrm{~h}$ at $25^{\circ} \mathrm{C}$. Alanine aminopeptidase activity was assayed using $1 \mathrm{mM}$ L-alanine-p-nitroanilide (Sigma) in $25 \mathrm{mM}$ Tris/ $\mathrm{HCl}$ buffer, $\mathrm{pH} \mathrm{7 \cdot 2}$. After incubation for $16 \mathrm{~h}$ at $37^{\circ} \mathrm{C}$, the release of free $p$-nitroaniline was measured by monitoring $A_{405}$. A unit of alanine aminopeptidase activity was defined as the quantity of enzyme that released $1 \mu \mathrm{mol} p$ nitroaniline in $1 \mathrm{~h}$ at $37^{\circ} \mathrm{C}$. The other enzyme activities were expressed in arbitrary units defined as: (difference of absorbance between the assay and the blank) $\times$ [(total vol. of the fluid)/(vol. of the assay)]. The localization index of a given enzyme was adapted from that previously proposed by Wiker et al. (1991) for mycobacterial antigens and was defined as the total extracellular activity per $\mathrm{mg}$ protein from the culture fluid divided by the total activity per $\mathrm{mg}$ protein in the cellbound compartment (cell extract plus cell envelope fractions).

The following activities were assayed in agar plates in $25 \mathrm{mM}$ Tris/ $\mathrm{HCl}$ buffer, $\mathrm{pH} 7 \cdot 2$ (Smibert \& Krieg, 1981) using $50 \mu \mathrm{l}$ $\left(50 \mu \mathrm{g}\right.$ protein $\left.\mathrm{ml}^{-1}\right)$ of the fraction, except for lipase activity, where both 10 and $50 \mu \mathrm{g}$ protein $\mathrm{ml}^{-1}$ concentrations of the fraction were used. Lipase was detected by incubating the fraction on agar plates supplemented with $1 \%(\mathrm{v} / \mathrm{v})$ sterile Tween 80 and $0.01 \% \mathrm{CaCl}_{2}$ for $2 \mathrm{~d}$ at $37^{\circ} \mathrm{C}$; a positive test was indicated by an opaque halo of crystals of calcium soap around the wells. Mucinase (Kannan et al., 1987) and hyaluronidase were detected in a similar way using $0.28 \%$ porcine stomach mucin and $0.1 \%$ hyaluronic acid from Streptococcus zooepidemicus (Sigma), respectively; the reactions were revealed by flooding the plates with cetrimide (Sigma). The occurrence of amylase and glycogenase was investigated using $0 \cdot 2 \%$ substrate and revealed with iodine vapour; similarly, gelatinase was assayed using $0.2 \%$ gelatin and the reaction was revealed using ethanol. DNase and RNase were assayed as described by Kannan et al. (1987). Other activities were measured following the hydrolysis of an insoluble substrate: $1 \%(\mathrm{w} / \mathrm{v})$ skimmed milk (Difco) for endopeptidase, $5 \%(\mathrm{v} / \mathrm{v})$ horse blood (bioMérieux) for haemolysin and $0.075 \%(\mathrm{w} / \mathrm{v})$ Micrococcus lysodeikticus lyophilized cells (Sigma) for lysozyme. In addition, endopeptidase activities were assayed in liquid conditions with $2 \%$ (w/v) chromogenic substrates, Azocasein, Elastin-Congo Red, Azo-dye-impregnated collagen or Hide Powder Azure (Sigma), $25 \mathrm{mM}$ Tris/HCl buffer, $\mathrm{pH} 7 \cdot 2$. After $16 \mathrm{~h}$ at $37^{\circ} \mathrm{C}$ the release of the free chromogen was monitored at $440,495,516$, and $630 \mathrm{~nm}$, respectively.

The following activities were assayed as indicated: alanine dehydrogenase (Andersen et al., 1992), alcohol dehydrogenase with $0 \cdot 8 \mathrm{M}$ butan-1,3-diol as substrate (de Bruyn et al., 1981), amidases (Bönicke, 1962), aminopeptidases (Muftic, 1967), asparaginase (Jayaram et al., 1968), glutamate dehydrogenase (Meers et al., 1970), glutamate synthase (Meers et al., 1970), glutamine synthetase (Woolfolk et al., 1966), glyceraldehyde3-phosphate dehydrogenase (Schraufstätter et al., 1988), neuraminidase (Warren, 1959), peroxidase (benzidine assay) (Buttiaux et al., 1966), phospholipase C (Kurioka \& Matsuda, 1976), pyruvate oxidase (Chang \& Cronan, 1982), superoxide dismutase (Paoletti \& Mocali, 1990) and thioredoxin/ thioredoxin reductase (Luthman \& Holmgren, 1982).

Routine tests used in microbiology to detect enzyme activities from agar or broth cultures were adapted to liquid media for the assays of the mycobacterial fractions. Urease, arginine hydrolase, lysine decarboxylase, ornithine decarboxylase and phenylalanine deaminase (Smibert \& Krieg, 1981) were revealed by alkalinization of the reaction medium and $\beta$ lactamase was detected by the hydrolysis of nitrocefin (Glaxo) (Kannan et al., 1987). The other tests used were as indicated: arylsulfatase (Smibert \& Krieg, 1981), carboxypeptidases A and B (Woodbury et al., 1981), catalase (Vincent LévyFrébault \& Portaels, 1992), $\alpha$ - and $\beta$-esterases (Vincent LévyFrébault \& Portaels, 1992), hippurate hydrolysis (Smibert \& Krieg, 1981; method 2), nitrate reductase (Smibert \& Krieg, 1981 ; method 2) and sodium $p$-aminosalicylate degradation (Tsukamura, 1966).

\section{RESULTS}

\section{Growth of $\boldsymbol{M}$. smegmatis and secretion of proteins}

It is well known that mycobacteria release various substances, including proteins, into their surrounding medium. However, depending on the physiological state of the cultures, the material may contain products originating from the cell envelope and/or the cytosolic compartment of the cell. Thus, the growth of $M$. smegmatis and the release of proteins into the culture medium during the different growth phases were investi- 

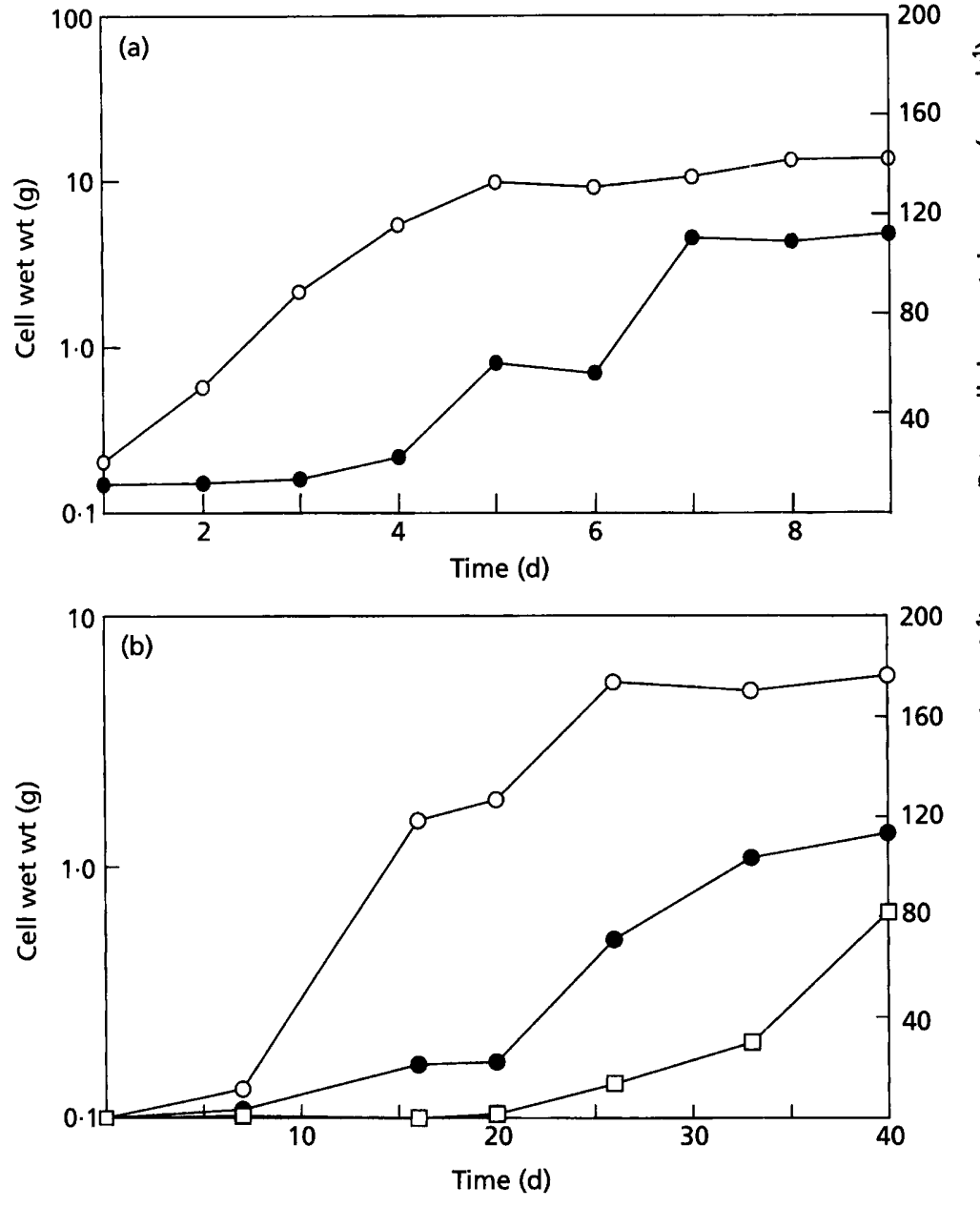

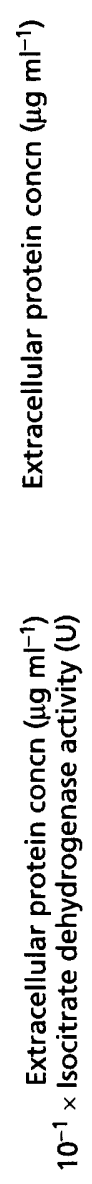

Fig. 1. Growth of (a) $M$. smegmatis ATCC 607 and (b) $M$. tuberculosis H37Rv. Mycobacteria were grown as surface pellicles on Sauton's medium $(100 \mathrm{ml}$ per flask) at $37^{\circ} \mathrm{C}$. Growth was monitored by measuring the cell wet weight $(O)$. Protein concentration (O) and total isocitrate dehydrogenase activity $(\square)$ of the culture broths were determined as described in Methods. gated over a period of $9 \mathrm{~d}$ (Fig. 1a). The bacilli multiplied for $3-4 \mathrm{~d}$, followed by a stationary phase. The release of proteins into the culture medium is a late phenomenon that reached its maximum intensity after the onset of the stationary phase.

The extracellular materials were assayed for the presence of enzymes whose cellular location is well known: isocitrate dehydrogenase, an indicator of autolysis (Andersen et al., 1991); alanine aminopeptidase, previously characterized in the cell envelope of $M$. smegmatis (Kilburn \& Best, 1977); and lipase (Akao et al., 1981), an actively secreted protein. The three activities were quantified throughout the growth phases in the culture medium and the cell extract. The Tween 80 hydrolase activity (Table 1 ) appeared in the culture filtrate from day 3 , while no isocitrate dehydrogenase activity was detected in the culture fluid. The cellenvelope-associated alanine aminopeptidase activity was detected in the culture fluid from the onset of the stationary phase, i.e. day 6 (Table 1 ), a result consistent with the previous observation that a maximum activity of this enzyme, which is presumably involved in the turnover of the cell wall, occurred in the late exponential phase of growth of M. smegmatis (Kilburn \& Best, 1977). This would explain the release of soluble materials from the cell envelope into the culture fluid. No isocitrate dehydrogenase activity was detected, however, in the culture fluids in the growth period examined. Thus, taken together, the distribution of the three enzyme activities in the different fractions is in complete agreement with their predicted location.

\section{Growth of $\boldsymbol{M}$. tuberculosis and secretion of proteins}

The growth of $M$. tuberculosis H37Rv was investigated over a period of $40 \mathrm{~d}$ in static cultures (Fig. 1b). The bacilli multiplied and reached the stationary phase after day 25. As in the case of M. smegmatis, the production of extracellular proteins by $M$. tuberculosis reached its maximum value after the onset of the stationary phase. The isocitrate dehydrogenase activity in the culture broth followed the growth curve: no activity was detected before day 20 , then an increased activity of the enzyme was observed in the culture fluid throughout the stationary phase. Thus, the enzyme activities present in the culture filtrate of $M$. tuberculosis H37Rv at day 16 were considered to derive from an extracellular location whereas those that appeared in older cultures are likely to have derived from the autolysis of the bacteria. 
Table 1. Selected enzyme activities of $M$. smegmatis

Total activities of enzymes in the cell extract (CE) and $100 \mathrm{ml}$ culture filtrate (CF) of $\mathrm{M}$. smegmatis are shown. The CE fraction corresponds to the $3000 \mathrm{~g}$ supernatant obtained after disrupting exponentially growing $M$. smegmatis cells with a French pressure cell. Isocitrate dehydrogenase and alanine aminopeptidase activities were determined at a protein concentration of $10 \mu \mathrm{g} \mathrm{ml}^{-1}$ at least three times; the values, in units as described in Methods, correspond to those obtained in a representative experiment. Lipase activity was determined in agar plates, as described in Methods, by incubating $50 \mu \mathrm{l}(0.5 \mu \mathrm{g}$ protein) of each fraction and the activity was expressed as the diameter (in $\mathrm{mm}$ ) of the hydrolysis zone. -, No activity detected.

\begin{tabular}{|c|c|c|c|c|c|c|}
\hline \multirow[t]{2}{*}{$\begin{array}{l}\text { Time } \\
\text { (d) }\end{array}$} & \multicolumn{2}{|c|}{$\begin{array}{c}\text { Isocitrate dehydrogenase } \\
\text { activity }(\mathrm{U})\end{array}$} & \multicolumn{2}{|c|}{$\begin{array}{c}\text { Alanine aminopeptidase } \\
\text { activity }(\mathrm{U})\end{array}$} & \multicolumn{2}{|c|}{$\begin{array}{c}\text { Lipase (Tween } 80 \text { hydrolase) } \\
\text { activity (hydrolysis zone, } \mathrm{mm} \text { ) }\end{array}$} \\
\hline & CE & CF & $\mathrm{CE}$ & CF & $\mathrm{CE}$ & CF \\
\hline 1 & $1 \cdot 2$ & - & $9 \cdot 6$ & - & 13 & - \\
\hline 2 & $6 \cdot 0$ & - & 83 & - & 16 & - \\
\hline 3 & $12 \cdot 6$ & - & 318 & - & 16 & 7 \\
\hline 4 & $13 \cdot 1$ & - & 3012 & - & 17 & 8 \\
\hline 5 & $3 \cdot 0$ & - & 4774 & - & 15 & 13 \\
\hline 6 & $23 \cdot 3$ & - & 4175 & 300 & 14 & 13 \\
\hline 7 & $33 \cdot 3$ & - & 5748 & 2340 & 13 & 14 \\
\hline 8 & $11 \cdot 5$ & - & 5548 & 4240 & 10 & 14 \\
\hline 9 & $46 \cdot 5$ & - & 5304 & 1720 & 11 & 13 \\
\hline
\end{tabular}

\section{Extracellular enzyme activities of $M$. smegmatis and M. tuberculosis}

To determine the enzyme profile of the two mycobacterial species, we first undertook a qualitative analysis of the enzyme profiles of the extracellular materials. Seventy-two enzyme activities were assayed throughout the different growth phases of $M$. tuberculosis $\mathrm{H} 37 \mathrm{Rv}$ and $M$. smegmatis. The tested activities included:(i) those enzymes previously described in mycobacteria, such as alanine dehydrogenase (Andersen et al., 1992), alcohol dehydrogenase (de Bruyn et al., 1981), glutamine synthetase (Harth et al., 1994), $\beta$-lactamase (Wagner et al., 1995), or phospholipase C (Johansen et al., 1996); (ii) the 19 activities detected by the API ZYM system (Casal \& Linares, 1984); (iii) the hydrolytic enzymes reported by Kannan et al. (1987); (iv) the enzyme activities used for identifying the various mycobacterial species (Tsukamura, 1981); (v) those used for the general characterization of bacteria (Smibert \& Krieg, 1981); (vi) enzymes previously described as virulence factors in pathogenic bacteria (Salyers \& Whitt, 1994).

Preliminary results demonstrated that some of the enzyme activities, especially those detected by the tests performed in agar plates and generally all the enzyme tests performed by incubating the culture fluids more than $16 \mathrm{~h}$ at $37^{\circ} \mathrm{C}$, may give false positive results, probably due to contamination with non-mycobacterial species. The fraction most susceptible to bacterial contamination was the dialysed culture fluid, probably because of the elimination of glycerol, which is known to be toxic for many bacterial species at high concentration. Consequently, we systematically added to each assay chloramphenicol and gentamicin at a con- centration of $100 \mu \mathrm{g} \mathrm{ml}^{-1}$, two broad-spectrum antibiotics which specifically inhibit the synthesis of bacterial proteins; in agreement with their mode of action, neither antibiotic interfered with the various assays performed.

A total of 14 and 19 extracellular enzyme activities, i.e. positive activities present in the culture fluids devoid of subsequent bacterial contamination and of isocitrate dehydrogenase, were detected in M. smegmatis and $M$. tuberculosis $\mathrm{H} 37 \mathrm{Rv}$, respectively. When more strains of M. tuberculosis were analysed, a total of 22 enzyme activites were revealed in the culture fluids of this species (Table 2), i.e. the 19 extracellular activities of H37Rv and three additional enzyme activities, namely catalase, peroxidase and lipase. Twelve enzyme activities were common to the culture filtrates of both species (group II, Table 2). A semi-quantitative analysis of these enzyme activities revealed that the corresponding enzymes were present in the two culture filtrates in similar concentrations. Thus, it is unlikely that these types of enzyme activities account for the pathogenicity of the tubercle bacillus. Interestingly, however, ten of the extracellular activities of $M$. tuberculosis, though present in the cell extract of $M$. smegmatis, were not detected in the $5 \mathrm{~d}$ culture filtrate of $M$. smegmatis (group I, Table 2), suggesting that they have either an envelope-associated or a cytosolic location in this latter species. Conversely, two enzyme activities present in the cell extracts of both species were detected in the culture fluid of $M$. smegmatis but not in that of M. tuberculosis (group III, Table 2).

Due to the great diversity of extracellular proteins produced by the two species, no relationship could be 
Table 2. Extracellular enzyme activities of $M$. tuberculosis and $M$. smegmatis

Activities were determined in 5-d-old (M. smegmatis) and 16-d-old (M. tuberculosis) culture broths devoid of isocitrate dehydrogenase activity, at a protein concentration of $50 \mu \mathrm{g} \mathrm{ml}^{-1}$. The activities detected in the culture fluid of two out of the three strains of M. tuberculosis examined (see Table 3 for details) are in bold.

\begin{tabular}{|lll|}
\hline $\begin{array}{l}\text { Group I (extracellular in } \\
\text { M. tuberculosis } \text { only) }\end{array}$ & $\begin{array}{c}\text { Group II (extracellular in } \\
\text { both strains) }\end{array}$ & $\begin{array}{c}\text { Group III (extracellular in } \\
\text { M. smegmatis } \text { only) }\end{array}$ \\
\hline $\begin{array}{l}\text { Alanine aminopeptidase } \\
\text { Cystine aminopeptidase }\end{array}$ & Arginine aminopeptidase & $\alpha$-Esterase \\
Alanine dehydrogenase & Leucine aminopeptidase & Tween 80 hydrolase \\
Glutamine synthetase & Proline aminopeptidase & \\
Nicotinamidase & Amylase & \\
Isonicotinamidase & $\beta$-Esterase \\
Superoxide dismutase & Esterase $\left(\mathrm{C}_{4}\right)$ \\
Alcohol dehydrogenase & Lipase esterase $\left(\mathrm{C}_{8}\right)$ & \\
Catalase & Lipase $\left(\mathrm{C}_{14}\right)$ & \\
Peroxidase & Acid phosphatase & \\
& Alkaline phosphatase & \\
& Phosphoamidase & \\
& $\beta$-Lactamase & \\
\hline
\end{tabular}

firmly established between the presence or the absence of a particular band on the SDS-PAGE and the published molecular masses of the secreted antigenic polypeptides (see Young et al., 1992) (data not shown). The use of available monoclonal antibodies directed against the purified enzymes confirmed the presence of the $40 \mathrm{kDa}$ alanine dehydrogenase in the culture filtrate of $M$. tuberculosis H37Rv (Andersen et al., 1992; OrtaloMagné et al., 1995), but this approach yields little information about the enzyme activity. Attempts to reveal the activities on gels were hampered by the irreversible denaturation of the enzymes on SDS-PAGE and the great difficulty of adapting most of the tests used for gel detection, notably those based on kinetic measurement of substrates. Accordingly, the ten enzyme activities present in the culture fluid of the tubercle bacillus and absent from that of the saprophytic species $M$. smegmatis were quantified using conventional methods.

\section{Quantification of the extracellular enzyme activities of $M$. tuberculosis}

Assuming that the potential role of an extracellular enzyme in pathogenesis depends in part on the relative quantity of the enzyme in the extracellular fluid, we investigated the distribution of the enzyme activities between the inside and the outside of M. tuberculosis cells and defined a localization index for the corresponding enzymes. Table 3 demonstrates that a significant part of the enzyme activities was found in the culture filtrate. Depending on the enzyme, the percentage of the total enzyme activity found in the culture fluid ranged from 17 to $92 \%$. The relative percentage of a given enzyme probably varies during the growth phases of the strain. Harth et al. (1994) reported that $30 \%$ of the glutamine synthetase of $M$. tuberculosis
$\mathrm{H} 37 \mathrm{Rv}$ was found in the culture filtrate whereas the extracellular portion of this enzyme was estimated in the present study to be $17 \%$ of the total bacterial activity of the same strain grown on the same culture medium. That the eight enzyme activities examined are probably due to secreted proteins was best seen when the activities were expressed relative to the amounts of proteins in the two cell compartments, i.e. the localization index (Table 3 ). The different activities were between fourfold and 134-fold more concentrated in the extracellular fluid than in the inside of the cells.

Interestingly, fractionation of the cell extract to yield a $20000 \mathrm{~g}$ pellet consisting mainly of cell envelope fragments demonstrated that this fraction contained only a negligible proportion $(0-1 \%)$ of most of the enzyme activities tested, further confirming that the activities correspond to secreted enzymes rather than proteins that reside in the cell envelope fraction. A notable exception was, however, alanine aminopeptidase; the enzyme activity found in the cell envelope fraction represented roughly $10 \%$ of the total bacterial content, in agreement with its putative location (Kilburn \& Best, 1977).

\section{Surface-located enzyme activities of $M$. smegmatis and $M$. tuberculosis}

To identify the enzymes that have a surface location and thus possess a potential role in the interaction between the bacteria and their environment, the amorphous material that covers cells of the two mycobacterial species was extracted with glass beads (Ortalo-Magné $e t$ al., 1995) and analysed for its enzyme content. As expected from the dynamics of the cell envelope (Daffé \& Draper, 1998), the different extracellular activities (Table 2) were also detected in the surface-located 
Table 3. Total activities and localization index of eight extracellular enzymes of $M$. tuberculosis H37Rv which are absent from the culture filtrate of $M$. smegmatis

The enzymes correspond to those of group $I$ in Table 2, except that catalase and peroxidase activities were absent from the culture filtrate of this strain. The activities (in units, as defined in Methods) were determined in the extracellular medium and the cell extract corresponding to the $3000 \mathrm{~g}$ supernatant obtained after disrupting the mycobacterial cells (16-d-old culture) as described in Methods. The fractions were tested at a protein concentration of $50 \mu \mathrm{g} \mathrm{ml}^{-1}$. The values are the mean of two independent experiments. The localization index corresponds to the extracellular enzyme activity per $\mathrm{mg}$ protein in the culture filtrate divided by the enzyme activity per mg protein in the cell-bound compartment.

\begin{tabular}{|c|c|c|c|}
\hline \multirow[t]{2}{*}{ Enzyme } & \multicolumn{2}{|c|}{ Total activity $(\mathbf{U})^{*}$} & \multirow{2}{*}{$\begin{array}{c}\text { Localization } \\
\text { index }\end{array}$} \\
\hline & Cell extract & Extracellular & \\
\hline Alanine aminopeptidase & $54 \cdot 0(56)$ & $42 \cdot 5(44)$ & $18 \cdot 8$ \\
\hline Cystine aminopeptidase & $28 \cdot 0(70)$ & $12 \cdot 3(30)$ & $4 \cdot 2$ \\
\hline Alanine dehydrogenase & $208 \cdot 8(65)$ & $70 \cdot 0(35)$ & $8 \cdot 0$ \\
\hline Glutamine synthetase & $3.7(83)$ & $0.7(17)$ & $4 \cdot 8$ \\
\hline Nicotinamidase & $7 \cdot 3(73)$ & $2 \cdot 7(27)$ & $9 \cdot 0$ \\
\hline Isonicotinamidase & $6 \cdot 0(60)$ & $4 \cdot 0(40)$ & $16 \cdot 0$ \\
\hline Superoxide dismutase & $282 \quad(8)$ & $1580 \quad\langle 92\rangle$ & $134 \cdot 0$ \\
\hline Alcohol dehydrogenase & $16 \cdot 8(58)$ & $13 \cdot 4(42)$ & $19 \cdot 0$ \\
\hline
\end{tabular}

* The numbers in parentheses correspond to the relative percentage of the activities present in each compartment.

Table 4. Localization of the ten enzyme activities selectively present in the culture broth of $M$. tuberculosis and absent from that of $M$. smegmatis in different mycobacterial species

Activities correspond to those in group I of Table 2. The growth curves of the different strains were determined and the isocitrate dehydrogenase activity was measured in the culture fluids. Based on the absence of this enzyme in the fluids, the enzyme activities were determined in the culture filtrates from day 4 (M. phlei), day 5 (M. smegmatis and M. fortuitum), day 12 (M. kansasii), day 15 (M. bovis BCG), day 16 (M. tuberculosis H37Rv), day 17 (M. tuberculosis Canetti) and day 20 (M. tuberculosis H37Ra). The extracellular and surface locations of the enzymes were defined according to whether the activity was detected in the indicated culture filtrates or the corresponding bead-extracted materials. When the activity was detected in the cell extract (the $3000 \mathrm{~g}$ supernatant) but not in the extracellular and surface-located material, the corresponding enzyme was considered as having an internal location. The fractions were tested at a protein concentration of $50 \mu \mathrm{g} \mathrm{ml}^{-1}$. Abbreviations: E, extracellular location; I, internal location; S, surface location. -, No activity detected.

\begin{tabular}{|c|c|c|c|c|c|c|c|c|}
\hline \multirow[t]{2}{*}{ Enzyme activity } & \multirow[t]{2}{*}{ M. smegmatis } & \multirow[t]{2}{*}{ M. phlei } & \multirow[t]{2}{*}{ M. fortuitum } & \multirow[t]{2}{*}{ M. kansasii } & \multicolumn{3}{|c|}{ M. tuberculosis } & \multirow[t]{2}{*}{ M. bovis } \\
\hline & & & & & H37Rv & H37Ra & Canetti & \\
\hline Alanine aminopeptidase & $S$ & $S$ & I & $\mathrm{E}$ & E & $\mathbf{E}$ & $\mathrm{E}$ & $\mathrm{E}$ \\
\hline Cystine aminopeptidase & $S$ & $S$ & $S$ & I & E & $\mathrm{E}$ & $\mathrm{E}$ & $\mathrm{E}$ \\
\hline Alanine dehydrogenase & I & I & I & $S$ & $\mathrm{E}$ & $\mathrm{E}$ & $\mathrm{E}$ & $\mathrm{E}$ \\
\hline Glutamine synthetase & I & I & - & - & $\mathrm{E}$ & $\mathrm{S}$ & $\mathrm{E}$ & $\mathrm{E}$ \\
\hline Nicotinamidase & I & I & $S$ & I & $\mathrm{E}$ & $\mathrm{E}$ & $\mathrm{E}$ & $\mathrm{E}$ \\
\hline Isonicotinamidase & I & I & $\mathrm{E}$ & $\mathrm{E}$ & $\mathrm{E}$ & $\mathrm{E}$ & E & $\mathrm{S}$ \\
\hline Superoxide dismutase & I & I & I & $\mathrm{I}$ & $\mathrm{E}$ & $\mathrm{E}$ & $\mathrm{E}$ & $\mathrm{E}$ \\
\hline Alcohol dehydrogenase & I & I & I & I & $\mathrm{E}$ & $\mathrm{E}$ & $S$ & $\mathrm{E}$ \\
\hline Catalase & I & I & I & $S$ & $S$ & $\mathrm{E}$ & $\mathrm{E}$ & $\mathrm{E}$ \\
\hline Peroxidase & I & I & I & $S$ & $S$ & $\mathrm{E}$ & $\mathrm{E}$ & $\mathrm{E}$ \\
\hline
\end{tabular}

materials of the corresponding strains examined. These materials did not show, however, any additional enzyme activities. As far as the ten selected extracellular enzyme activities of $M$. tuberculosis are concerned (group I,
Table 2), the enzyme activities that were absent from one of the three strains of $M$. tuberculosis examined (Table 2) were easily detected in the surface-exposed material (Table 4). For instance, catalase and peroxidase 
Table 5. Localization of some extracellular enzymes in the capsules of $M$. tuberculosis H37Rv and $M$. smegmatis by gradual erosion of their envelopes

Cells were eroded with glass beads (treatment 1), Tween 80 for $1 \mathrm{~h} \mathrm{(2),} \mathrm{Tween} 80$ for $4 \mathrm{~h}$ (3), glass beads after treatment with Tween 80 for $1 \mathrm{~h} \mathrm{(4)}$ or $4 \mathrm{~h} \mathrm{(5),} \mathrm{Tween} 80$ for $24 \mathrm{~h} \mathrm{(6)}$ and glass beads after treatment with Tween 80 for $24 \mathrm{~h}$ (7). The various enzyme activities were measured as described in Methods. +, Activity detected; - , no activity detected.

\begin{tabular}{|c|c|c|c|c|c|c|c|c|c|c|c|c|c|c|c|}
\hline \multirow[t]{2}{*}{ Enzyme activity } & \multirow[b]{2}{*}{ Treatment ... } & \multicolumn{7}{|c|}{ M. tuberculosis } & \multicolumn{7}{|c|}{ M. smegmatis } \\
\hline & & 1 & 2 & 3 & 4 & 5 & 6 & 7 & 1 & 2 & 3 & 4 & 5 & 6 & 7 \\
\hline Superoxide dismutase & & + & + & + & + & + & + & + & - & - & - & - & - & - & - \\
\hline Nicotinamidase & & + & + & + & + & + & + & + & - & - & - & - & - & - & + \\
\hline Isonicotinamidase & & + & + & + & + & + & + & + & - & - & - & - & - & - & + \\
\hline Catalase & & + & + & + & + & + & + & + & - & - & - & - & + & + & + \\
\hline Peroxidase & & + & + & + & + & + & + & + & - & - & - & - & + & + & + \\
\hline Alanine dehydrogenase & & + & + & + & + & + & + & + & - & + & + & + & + & + & + \\
\hline Alcohol dehydrogenase & & + & + & + & + & + & + & + & - & + & + & + & + & + & + \\
\hline Glutamine synthetase & & + & + & + & + & + & + & + & - & + & + & + & + & + & + \\
\hline$\alpha$-Esterase & & - & - & - & - & - & + & + & + & + & + & + & + & + & + \\
\hline Tween -80 hydrolase & & - & - & - & - & - & - & - & + & + & + & + & + & + & + \\
\hline
\end{tabular}

activities, which were not detected in the culture filtrate of strain $\mathrm{H} 37 \mathrm{Rv}$, were readily measurable in the material extracted with glass beads from this bacterium. Examination of these materials also revealed that two out of the ten selected extracellular enzyme activities of $M$. tuberculosis, i.e. alanine and cystine aminopeptidases, were present on the cell surface of $M$. smegmatis. The remaining eight activities were detected neither in the culture filtrate nor in the outermost cell envelope material of M. smegmatis.

\section{Localization in $\boldsymbol{M}$. smegmatis of some extracellular enzyme activities detected in $M$. tuberculosis}

The absence in M. smegmatis of a set of extracellular and surface-exposed enzymes that are found in $M$. tuberculosis may be explained by either a cytosolic location or an internal capsular location of these enzymes in M. smegmatis. To locate these eight extracellular enzyme activities (see above), we extracted the capsular materials covering $M$. smegmatis cells stepwise with Tween 80 for 1,4 or $24 \mathrm{~h}$ and with glass beads, a method known to expose internal capsular constituents (Ortalo-Magné et al., 1996). Analysis of the extracted materials (Table 5) showed a marked difference in the location of the various enzyme activities in the cell envelope compartments of $M$. smegmatis. The alanine dehydrogenase, alcohol dehydrogenase and glutamine synthetase activities were detected in the materials resulting from the treatment of cells with Tween 80 for $1 \mathrm{~h}$ or longer, as well as in the materials recovered from the bacilli treated with glass beads. The catalase and the peroxidase activities were located in a more internal compartment of the capsule than the three former enzymes, since they were not detected prior to the treatment of cells with Tween 80 for $4 \mathrm{~h}$, followed by the action of glass beads on the treated bacilli. The resulting material contained both enzymes (Table 5). The nicotinamidase and isonicotinamidase activities were found buried more deeply in the capsule of $M$. smegmatis than the five other enzymes since the corresponding activities were not measurable prior to the treatment of the bacilli with Tween 80 for $24 \mathrm{~h}$. Although the superoxide dismutase activity was easily characterized in the cell extract of $M$. smegmatis, no detectable activity of this enzyme was found in the different Tween 80 extracts examined. It follows then that, with the possible exception of superoxide dismutase, which may be located in the cell wall or in the cytosol, the extracellular enzyme activities of $M$. $t u$ berculosis examined here are present in various internal compartments of the capsule of M. smegmatis.

\section{Localization in $\boldsymbol{M}$. tuberculosis of some extracellular enzyme activities of $M$. smegmatis}

The location of the two extracellular enzyme activities of $M$. smegmatis not detected in the culture fluid of $M$. tuberculosis (group III, Table 2) was also investigated by measuring the activities in the materials extracted from the tubercle bacillus with Tween 80 and glass beads (Ortalo-Magné et al., 1996). The erosion of regions of the capsule of $M$. tuberculosis by treating cells with Tween 80 for 1 or $4 \mathrm{~h}$ and the subsequent use of glass beads did not expose the two enzymes on the bacterial surface. A treatment with Tween 80 for $24 \mathrm{~h}$ was necessary to extract of the $\alpha$-esterase activity but no Tween 80 hydrolase activity was detected (Table 5). This latter enzyme, though present in the cytosol, was not detectable in the various compartments of the capsule, suggesting that the enzyme is located either more deeply in the cell wall or in the cytosol of $M$. tuberculosis. 
Extracellular and surface-located enzyme activities of other mycobacterial species

To further evaluate the potential biological significance of the ten extracellular and surface-located enzymes of the obligate pathogen M. tuberculosis (group I, Table 2), we compared the enzyme profiles of M. bovis BCG (a member of the $M$. tuberculosis complex), a rapidgrowing ( $M$. fortuitum) and a slow-growing ( $M$. kansasii) opportunistic pathogen, and an additional non-pathogenic species (M. phlei) (Table 4). This resulted in the classification of the examined strains into three groups: (i) the obligate pathogens (the $M$. $t u$ berculosis-bovis complex) which invariably secrete or expose on their surfaces the ten enzymes listed in Table 4; (ii) the non-pathogens M. smegmatis and M. phlei, in which most of these enzymes are neither secreted nor surface-located; (iii) the opportunistic pathogens that secrete or expose on their surfaces some of these enzymes. As the growth rates of the species are not correlated with their extracellular enzyme profiles, the difference in the secretion and/or exposure of enzymes such as superoxide dismutase, catalase, peroxidase, glutamine synthetase and alanine dehydrogenase are more likely to be related to the degree of pathogenicity of the organisms rather than to their growth rate.

\section{DISCUSSION}

To evaluate the contribution of extracellular enzymes to the pathogenicity of the tubercle bacillus, the enzyme activities of $M$. tuberculosis were determined and compared to those of other mycobacterial species, including obligate and opportunistic pathogens, and non-pathogenic species. To achieve this, the enzyme profiles of $M$. tuberculosis and M. smegmatis were first determined throughout their different growth phases to differentiate clearly between extracellular enzymes and those derived from the release of surface-located or cytosolic material into the culture filtrate. This approach led us to use culture fluids devoid of any detectable isocitrate dehydrogenase activity, a marker of cell lysis, and to perform the enzyme tests in conditions that prevent commonly occurring bacterial contamination. Our results are generally in agreement with the data in the literature. Eight extracellular enzyme activities were found to be present in the culture fluids and/or on the cell surfaces of M. tuberculosis and M. bovis, and absent from those of the non-pathogenic species $M$. smegmatis and M. phlei, in which these enzymes are located more deeply in their cell envelopes. Interestingly, the opportunistic mycobacterial pathogens examined, $M$. kansasii and $M$. fortuitum, secrete and/or expose some of these enzymes, further supporting their possible implication in mycobacterial pathogenicity. In addition, the presence of some enzymes, namely alcohol dehydrogenase, glutamine synthetase and superoxide dismutase, in the outermost compartments of only $M$. tuberculosis and $M$. bovis BCG suggest a potential role for these enzymes in the pathogenesis of tuberculosis.

The possible implication of some of these extracellular enzymes of $M$. tuberculosis in the pathogenesis of $M$. tuberculosis infections is also supported by data from the literature. For instance, Harth et al. (1994) have suggested that extracellular glutamine synthetase would principally catalyse the synthesis of the L-glutamine component of the L-glutamate/glutamine polymer assumed to be primarily present in the cell envelope of the virulent strains of the $M$. tuberculosis complex (Migliore et al., 1966; Wietzerbin et al., 1975). In addition, glutamine synthetase, which can release ammonia from glutamine, the most abundant amino acid of the host cells (Barclay \& Wheeler, 1989), may contribute to the capacity of $M$. tuberculosis to inhibit phagosome acidification and phagosome-lysosome fusion in infected monocytes. This hypothesis would account for the fact that glutamine synthetase was more concentrated in the culture fluid of pathogenic mycobacteria (Harth et al., 1994 and Table 4). Similarly, alanine dehydrogenase has been shown to be released in substantial amounts into the culture medium of virulent strains of M. tuberculosis only (Andersen et al., 1992), a finding that would suggest a role for alanine dehydrogenase in the virulence of $M$. tuberculosis. Its involvement in nitrogen metabolism, releasing ammonia from alanine, the second most abundant amino acid in the extracellular fluid of the host (Barclay \& Wheeler, 1989), would also suggest a role for alanine dehydrogenase in the inhibition of the phagosome acidification. Likewise, the catalase-negative mutants of $M$. tuberculosis that are frequently resistant to isoniazid (Middlebrook, 1954) are known to exhibit lower virulence towards guinea pigs than the parent strains (Middlebrook \& Cohn, 1953). Furthermore, integration of a functional kat $G$, a gene that encodes catalaseperoxidase, into an attenuated catalase-negative strain of $M$. bovis restored full virulence for guinea pigs (Wilson et al., 1995), thereby establishing that catalase and/or peroxidase are virulence factors at least in this host. These enzymes, as well as superoxide dismutase, have been regarded for a long time as putative candidates to resist the toxic oxygen intermediates produced by host phagocytes. In the case of superoxide dismutase, this hypothesis is largely founded on the unusual extracellular localization of superoxide dismutase, which has a cytosolic location in most non-pathogenic species of mycobacteria (Escuyer et al., 1996). Our finding that superoxide dismutase is located extracellularly in $M$. tuberculosis and in the cell wall or the cytosol of M. smegmatis supports this hypothesis. The significance of the other extracellular enzymes selectively present in $M$. tuberculosis in the virulence of this bacterium is rather unclear, although extracellular nicotinamidase may be involved in its characteristic niacin production. Application of molecular biological methods to mycobacteria should help establish the importance of the extracellular enzymes that we propose as being involved in the pathogenicity of $M$. tuberculosis.

These enzymes are not necessarily the only important extracellular ones for mycobacterial pathogenicity, as 
the use of a synthetic culture medium could prevent the production of inducible hydrolytic enzymes. Indeed, previous results have shown that at least gelatinase (Imboden et al., 1996), fibrinogen and elastin hydrolase (Dave et al., 1996), urease (Clemens et al., 1995) or phospholipase (Wheeler \& Ratledge, 1992) activities can be induced or strongly stimulated according to the culture medium. Cultivating the micro-organisms on media containing various substrates mimicking the environment of infected cells would complement the present approach.

Finally, a significant aspect of the present work is the finding that some extracellular enzymes of $M$. tuberculosis reside in internal compartments of the cell envelope of $M$. smegmatis and vice versa. It has been recently shown by Escuyer et al. (1996) that M. smegmatis, a species in which superoxide dismutase is strictly cytosolic, upon transformation by the gene from $M$. avium that encodes the enzyme was able to expose on its cell surface and even release the enzyme into the culture fluid in conditions where autolysis was estimated to be minimal. This result suggested that $M$. avium and pathogenic mycobacterial species differ from $M$. smegmatis in the secretion of superoxide dismutase through the cytoplasmic membrane. By showing the localization of seven extracellular enzyme activities, presumaby from secreted proteins, of M. tuberculosis in the cell envelope of $M$. smegmatis, we have demonstrated that mycobacterial species also differ in the exposure on their surfaces and secretion (into their environment) of some proteins. While M. tuberculosis and some pathogenic species examined here secrete and/or expose on their surface some enzymes potentially involved in the pathogenicity, they neither secrete nor expose other proteins, such as $\alpha$-esterase and Tween 80 hydrolase. These data point to a fundamental difference in the architecture of the cell envelopes of pathogenic and non-pathogenic mycobacteria, and suggest that further study of the mechanisms involved in the secretion or excretion of macromolecules through the mycobacterial cell envelopes is warranted.

\section{ACKNOWLEDGEMENTS}

This work was supported in part by a grant (no. 9609714) from the Région Midi Pyrénées (Toulouse, France).

\section{REFERENCES}

Abou-Zeid, C., Smith I., Grange, J., Steele, J. \& Rook, G. (1986). Subdivision of daughter strains of Bacille Calmette-Guérin (BCG) according to secreted protein patterns. J Gen Microbiol 132, 3047-3053.

Akao, T., Kusaka, T. \& Kobashi, K. (1981). Two esterases released from Mycobacterium smegmatis for the hydrolysis of long chain acyl-CoAs and Tween. J Biochem 90, 1661-1669.

Andersen, A. B. \& Brennan, P. (1994). Proteins and antigens of Mycobacterium tuberculosis. In Tuberculosis: Pathogenesis, Protection and Control, pp. 307-332. Edited by B. R. Bloom. Washington, DC: American Society for Microbiology.

Andersen, A. B., Andersen, P. \& Ljungqvist, L. (1992). Structure and function of a 40,000-molecular-weight protein antigen of Mycobacterium tuberculosis. Infect Immun 60, 2317-2323.

Andersen, P., Askgaard, D., Ljungqvist, L., Bennedsen, J. \& Heron, I. (1991). Proteins released from Mycobacterium tuberculosis during growth. Infect Immun 59, 1905-1910.

Barclay, R. \& Wheeler, P. R. (1989). Metabolism of mycobacteria in tissues. In The Biology of the Mycobacteria, vol. 3, Clinical Aspects of Mycobacterial Disease, pp. 37-106. Edited by C. Ratledge, J. Stanford \& J. M. Grange. San Diego, CA : Academic Press.

Bloom, B. R. \& Murray, C. J. L. (1992). Tuberculosis : commentary on a reemergent killer. Science 257, 1055-1064.

Bönicke, R. (1962). L'identification des mycobactéries à l'aide de méthodes biochimiques. Bull Un Int Tuberc 32, 13-76.

de Bruyn, J., Johannes, A., Weckx, M. \& Beumer-Jochmans, M.-P. (1981). Partial purification and characterization of an alcohol dehydrogenase of Mycobacterium tuberculosis var. bovis (BCG). J Gen Microbiol 124, 359-363.

Buttiaux, R., Beerens, H. \& Tacquet, A. (1966). Mycobactéries. Recherche des mycobactéries dans les produits pathologiques. Techniques d'isolement et d'identification. In Manuel de Techniques Bactériologiques, 2nd edn, pp. 540-541. Paris: Editions Médicales Flammarion.

Casal, M. \& Linares, M. J. (1984). Enzyme profile of Mycobacterium tuberculosis. Eur J Clin Microbiol 3, 155-156.

Chang, Y.-Y. \& Cronan, J. E. Jr (1982). Mapping non-selectable genes of Escherichia coli by using transposon Tn10: location of a gene affecting pyruvate oxidase. J Bacteriol 151, 1279-1289.

Clemens, D. L., Lee, B.-Y. \& Horwitz, M. A. (1995). Purification, characterization and genetic analysis of Mycobacterium tuberculosis urease, a potentially critical determinant of host-pathogen interaction. J Bacteriol 177, 5644-5652.

Cossart, P., Boquet, P., Normark, S. \& Rappuoli, R. (1996). Cellular microbiology emerging. Science 271, 315-316.

Daffé, M. (1996). Structure de l'enveloppe de Mycobacterium tuberculosis. Méd Mal Infect 26, 891-897.

Daffé, M. \& Draper, P. (1998). The envelope layers of mycobacteria with reference to their pathogenicity. Adv Microb Physiol 39, 131-20.3.

Dave, J. A., Schwager, S. L. U., Scholle, R. R. \& Ehlers, M. R. W. (1996). Detection of proteases produced by Mycobacterium tuberculosis under defined culture conditions. In Abstracts of the Third International Conference on the Pathogenesis of Mycobacterial Infections, Stockholm, p. 59.

Draper, P. \& Rees, R. J. W. (1970). Electron transparent zone of mycobacteria may be a defence mechanism. Nature 228, 860-861.

Escuyer, V., Haddad, N., Frehel, C. \& Berche, P. (1996). Molecular characterization of a surface-exposed superoxide dismutase of Mycobacterium avium. Microb Pathog 20, 41-55.

Harth, G., Clemens, D. L. \& Horwitz, M. A. (1994). Glutamine synthetase of Mycobacterium tuberculosis: extracellular release and characterization of its enzyme activity. Proc Natl Acad Sci USA 91, 9342-9346.

Imboden, P., Rane, S., Small, P. \& Schoolnik, G. K. (1996). Regulation of Mycobacterium tuberculosis gene expression by oxygen tension. In Abstracts of the Third International Conference on the Pathogenesis of Mycobacterial Infections, Stockbolm, p. 3.

Jayaram, H. N., Ramakrishnan, T. \& Vaidyanathan, C. S. (1968). L-Asparaginases from Mycobacterium tuberculosis strains H37Rv and H37Ra. Arch Biochem Biophys 126, 165-174. 
Johansen, K. A., Gill, R. E. \& Vasil, M. L. (1996). Biochemical and molecular analysis of phospholipase $\mathrm{C}$ and phospholipase D activity in mycobacteria. Infect Immun 64, 3259-3266.

Kannan, K. B., Katoch, V. M., Sharma, V. D. \& Bharadwaj, V. P. (1987). Extracellular enzymes of mycobacteria. FEMS Microbiol Lett 48, 31-33.

Kilburn, J. O. \& Best, G. K. (1977). Characterization of autolysins from Mycobacterium smegmatis. J Bacteriol 29, 750-755.

Kurioka, S. \& Matsuda, M. (1976). Phospholipase C assay using $p$ nitrophenylphosphoryl-choline together with sorbitol and its application to studying the metal and detergent requirement of the enzyme. Anal Biochem 75, 281-289.

Lemassu, A. \& Daffé, M. (1994). Structural features of the exocellular polysaccharides of Mycobacterium tuberculosis. Biochem J 297, 351-357.

Lemassu, A., Ortalo-Magné, A., Bardou, F., Silve, G., Lanéelle, M.-A. \& Daffé, M. (1996). Extracellular and surface-exposed polysaccharides of non-tuberculous mycobacteria. Microbiology 142, 1513-1520.

Luthman, M. \& Holmgren, A. (1982). Rat liver thioredoxin and thioredoxin reductase: purification and characterization. Biochemistry 21, 6628-6633.

Meers, J. L., Tempest, D.W. \& Brown, C. M. (1970). Glutamine(amide):2-oxoglutarate amino transferase oxido-reductase (NADP), an enzyme involved in the synthesis of glutamate by some bacteria. J Gen Microbiol 64, 187-194.

Middlebrook, G. (1954). Isoniazid-resistance and catalase activity of tubercle bacilli. Am Rev Tuberc 69, 471-472.

Middlebrook, G. \& Cohn, M. L. (1953). Some observations on the pathogenicity of isoniazid-resistant variants of tubercle bacilli. Science 118, 297-299.

Migliore, D., Acharya, N. P. V. \& Jollès, P. (1966). Caractérisation de quantités importantes d'acide glutamique dans les parois de mycobactéries de souches humaines virulentes. C R Acad Sci Ser D 263, 846-848.

Moran, N. (1996). WHO issues another gloomy tuberculosis report. Nature Medicine 2, 377.

Muftic, M. (1967). Application of chromogenic substrates to the determination of peptidases in mycobacteria. Folia Microbiol 12, 500-507.

Nagai, S., Wiker, H. G., Harboe, M. \& Kinomoto, M. (1991). Isolation and partial characterization of major protein antigens in the culture fluid of Mycobacterium tuberculosis. Infect Immun 59, 372-382.

Ortalo-Magné, A., Dupont, M.-A., Lemassu, A., Andersen, A. B., Gounon, P. \& Daffé, M. (1995). Molecular composition of the outermost capsular material of the tubercle bacillus. Microbiology 141, 1609-1620.

Ortalo-Magné, A., Lemassu, A., Lanéelle, M.-A., Bardou, F., Silve, G., Gounon, P., Marchal, G. \& Daffé, M. (1996). Identification of the surface-exposed lipids on the cell envelopes of Mycobacterium tuberculosis and other mycobacterial species. J Bacteriol 178, $456-461$.

Paoletti, F. \& Mocali, A. (1990). Determination of superoxide dismutase activity by purely chemical system based on $\mathrm{NAD}(\mathrm{P}) \mathrm{H}$ oxidation. Methods Enzymol 186, 209-220.

Salyers, A. A. \& Whitt, D. D. (1994). Bacterial Pathogenesis, a Molecular Approach. Washington, DC: American Society for Microbiology.

Sauton, B. (1912). Sur la nutrition minérale du bacille tuberculeux. C R Acad Sci Ser III Sci Vie 155, 860-863.
Schraufstätter, I. U., Halsey, W. A., Jr, Hyslop, P. A. \& Cochrane, C. G. (1988). In vitro models for the study of oxidant-induced injury of cells in inflammation. Methods Enzymol 163, 328-340.

Sears, C. L. \& Kaper, J. B. (1996). Enteric bacterial toxins: mechanisms of action and linkage to intestinal secretion. Microbiol Rev 60, 167-215.

Smibert, R. M. \& Krieg, N. R. (1981). General characterization. In Manual of Methods for General Bacteriology, pp. 409-443. Edited by P. Gerhardt and others. Washington, DC: American Society for Microbiology.

Travis, J., Potempa, J. \& Maeda, H. (1995). Are bacterial proteinases pathogenic factors? Trends Microbiol 3, 405-407.

Tsukamura, M. (1966). Adansonian classification of mycobacteria. J Gen Microbiol 45, 253-273.

Tsukamura, M. (1981). A review of the methods of identification and differentiation of mycobacteria. Rev Infect Dis 3, 841-861.

Vincent Lévy-Frébault, V. \& Portaels, F. (1992). Proposed minimal standards for the genus Mycobacterium and for description of new slowly growing Mycobacterium species. Int J Syst Bacteriol $42,315-323$.

Wagner, B., Fattorini, L., Wagner, M., Jin, S.-H., Stracke, R., Amicosante, G., Franceschini, N. \& Orefici, G. (1995). Antigenic properties and immunoelectron microscopic localization of Mycobacterium fortuitum $\beta$-lactamase. Antimicrob Agents Chemother 39, 739-745.

Warren, L. (1959). The thiobarbituric acid assay of sialic acids. J Biol Chem 234, 1971-1975.

Wheeler, P. R. \& Ratledge, C. (1992). Control and location of acylhydrolysing phospholipase activity in pathogenic mycobacteria. $J$ Gen Microbiol 138, 825-830.

Wieles, B., Nagai, S., Wiker, H. G., Harboe, M. \& Ottenhoff, T. H. M. (1995). Identification and functional characterization of thioredoxin of Mycobacterium tuberculosis. Infect Immun 63, 4946-4948.

Wietzerbin, J., Lederer, F. \& Petit, J.-F. (1975). Structural study of the poly-L-glutamic acid of the cell wall of Mycobacterium tuberculosis var hominis, strain Brevannes. Biochem Biophys Res Commun 62, 246-252.

Wiker, H. G., Harboe, M. \& Nagai, S. (1991). A localization index for distinction between extracellular and intracellular antigens of Mycobacterium tuberculosis. J Gen Microbiol 137, 875-884.

Wilson, T. M., de Lisle, G. W. \& Collins, D. M. (1995). Effect of inhA and $k a t G$ on isoniazid resistance and virulence of Mycobacterium bovis. Mol Microbiol 15, 1009-1015.

Woodbury, R. G., Everitt, M. T. \& Neurath, H. (1981). Mast cell proteases. Methods Enzymol 80, 588-609.

Woolfolk, C. A., Shapiro, B. \& Stadtman, E. R. (1966). Regulation of glutamine synthetase. I. Purification and properties of glutamine synthetase from Escherichia coli. Arch Biochem Biophys 116, 177-192.

Young, D. B., Kaufman, S. H. E., Hermans, P. W. M. \& Thole, J. E. R. (1992). Mycobacterial protein antigens: a compilation. Mol Microbiol 6, 133-145.

Zhang, Y., Lathigra, R., Garbe, T., Catty, D. \& Young, D. (1991). Genetic analysis of superoxide dismutase, the 23 kilodalton antigen of Mycobacterium tuberculosis. Mol Microbiol 5, 381-391.

Received 8 August 1997; revised 2 October 1997; accepted 8 October 1997. 